\title{
Spatio-temporal dynamics of Alticini (Coleoptera, Chrysomelidae) in a fragment of Araucaria Forest in the state of Parana, Brazil ${ }^{1}$
}

\author{
Adelita Maria Linzmeier ${ }^{2} \&$ Cibele Stramare Ribeiro-Costa ${ }^{2}$
}

${ }^{1}$ Contribution number 1782 of Departamento de Zoologia of the Universidade Federal do Paraná.

${ }^{2}$ Laboratório de Sistemática e Bioecologia de Coleoptera (Insecta), Departamento de Zoologia, Universidade Federal do Paraná, Caixa Postal 19020, 81531-980 Curitiba-PR, Brazil. Fellowships CNPq. alinzmeier@yahoo.com.br; stra@ufpr.br

\begin{abstract}
Spatio-temporal dynamics of Alticini (Coleoptera, Chrysomelidae) in a fragment of Araucaria Forest in the state of Parana, Brazil. Alticini fauna from five areas, two with different types of management (Borda and Araucaria) and three with different levels of conservation (Fase 1, Fase 2 and Fase 3), in the Araucaria Forest of the Parana was captured with malaise traps. The material was collected weekly, from September/1999 to August/2001, in the Parque Estadual of Vila Velha, Ponta Grossa. 1,891 individuals of 106 Alticini species were collected with only seven species common to all areas. Despite the proximity between sampling areas, the number of species shared between pairs of areas was low, not reaching $40 \%$, with the Araucaria and Fase 1 areas being the most similar. The community structure of the areas Fase 1 and Fase 2 were most related. Fase 1, in initial stage of succession, showed the largert variation in the abundance and richness from one year to another.
\end{abstract}

KEYWORDS. Abundance; beta diversity; community structure; flea beetles, malaise.

RESUMO. Dinâmica espaço-temporal de Alticini (Coleoptera, Chrysomelidae) em um fragmento de Floresta com Araucária no Paraná, Brasil. A fauna de Alticini foi inventariada em cinco áreas, duas com diferentes tipos de manejo (Borda e Araucária) e três em diferentes níveis de conservação (Fase 1, Fase 2 e Fase 3), na Floresta com Araucária do Paraná. Os insetos foram coletados semanalmente, com o uso de armadilha malaise, de setembro/1999 a agosto/2001. No total foram coletados 1.891 exemplares de Alticini pertencentes a 106 espécies das quais apenas sete foram comuns a todas as áreas. Apesar da proximidade entre as áreas o número de espécies compartilhadas foi baixo, não atingindo $40 \%$, com as áreas Araucária e Fase 1 sendo as mais similares. A estrutura das comunidades das áreas Fase 1 e Fase 2 mostraramse mais relacionadas. A área Fase 1, em estágio inicial de sucessão, apresentou a maior variação, tanto na abundância quanto na riqueza, de um ano para outro.

PALAVRAS-CHAVE. Abundância; alticíneos; diversidade beta; estrutura de comunidade; malaise.

While alfa diversity and gamma diversity are counting of species in a particular area, the beta diversity indicates the changes in the species composition among communities, both spatially as temporally (Magurran 2004; Novotny \& Weiblen 2005). Such changes may be related to historical factors such as the geographic range of species, the presence of geographical barriers and, ecological factors, such as dispersion, habitat or landscape heterogeneity and isolation (Didham et al. 1998; Leps et al. 2001; Gering \& Crist 2002; Driscoll \& Weir 2005).

Studies of beta diversity are very important to understand how communities change in the different ecosystems, in response to natural and human induced phenomena. The Araucaria Forest is one of the major phytophysiognomies of Southern Region of Brazil, both for its extension as by its exclusiveness (Castella et al. 2004). In Parana State, the Araucaria Forest originally covered about $37 \%$ of the state area (Maack 1981). Currently less than $1 \%$ are well preserved while the remaining, are very fragmented and has suffering a continuous process of degradation (Britez et al. 2000; Fupef 2001; Castella et al. 2004). Within Araucaria Forest domain, the Parque Estadual de Vila Velha with 3,803.28 ha is a Conservation Unit that harbors a portion of the Araucaria Forest in different levels of conservation and management which makes this conservation unit suitable to study process of beta diversity.

Approximately $45 \%$ of all insect species are herbivores (Frenzel \& Brandl 2001) and among these, Chrysomelidae stands out as one of the hyper diverse coleopteran families. Within Chrysomelidae, Alticini (Galerucinae), with about 11,000 described species (Jolivet \& Petitpierre 1976; Furth 1988; Scherer 1988), is the most commonly collected group in different regions of the world using different methodologies (Farrel \& Erwin 1988; Takizawa 1994; Basset \& Samuelson 1996; Wagner 1999; Novotný et al. 1999; Linzmeier et al. 2006). The most Alticini species are highly specialized, feeding mainly on Solanaceae, Cruciferae, Resedaceae, Capparidaceae, Verbenaceae, Labiatae and Asteraceae (Jolivet 1988, Jolivet \& Hawkeswood 1995).

The purpose of this study is to provide better understanding of the beta diversity of phytophagous beetles, both in space and time, in areas that present the vegetation in different levels of conservation and management. Through 
the more standardized methods of collection and longer periods of sampling, the interpretations of such changes will be more consistent.

Alticini, being a specialized phytophagous group, could be sensitive to environmental changes and then, to respond to different levels of conservation. Thus, we hypothesize that Alticini communities will be more similar in areas that present similar vegetation structure and composition than in areas with different structure.

\section{MATERIALAND METHODS}

This survey took place in the Parque Estadual of Vila Velha

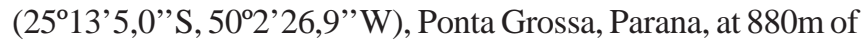
altitude, from August 30, 1999 to August 27, 2001.

Five sampling areas were selected in a fragment of Araucaria forest inside the park: an edge of grassland-forest (Borda), an area of unmanaged araucaria reforestation (Araucaria), and three areas in different successional stages: initial to intermediary succession (Fase 1), intermediary to advanced succession (Fase 2) and advanced succession (Fase 3). Detailed information about these areas could be found in Ganho \& Marinoni (2003). In each sampling area a malaise trap was placed (Townes 1972) from which the insects were removed weekly from September 1999 to August 2001.

All Alticini were identified to the lowest taxonomic level possible, using relevant bibliography and comparing with identified material belonging to Coleção de Entomologia Pe. Jesus Santiago Moure (DZUP), Museu de Ciências Naturais, Fundação Zoobotânica do Rio Grande do Sul (MCNZ) and Museu Anchieta, Porto Alegre (MAPA).

The specimens from this study were deposited in the Coleção de Entomologia Pe. J. S. Moure of the Departamento de Zoologia, Universidade Federal do Paraná.

In order to determine the similarity among the areas, both in space and time, cluster analyses were performed, using the Jaccard and Morisita-Horn Coefficients (Magurran 2004), with the formation of the groups through UPGMA method (Unweighted Pair Group Method-Averages). The analyses were performed in the program NTSYS-pc (Numerical Taxonomy and Multivariate Analysis System), Version 1.50 (Rohlf 1989).

The spatial analyses were based on data collected from the entire period (September/1999 to August/2001). To the temporal analysis, were compared the first year data (September/1999 to August/2000) with the second year data of collection (September/2000 to August/2001) from each area.

\section{RESULTS}

Spatial dynamics

Community Structure: A total of 1,891 specimens of Alticini were collected during the two sampling years. The highest abundance was recorded in the area with intermediate stage of succession, Fase 2, and the lowest was in the Borda area (Table I).
Regarding the community structure, the areas Fase 1 and Fase 2 were the most similar. Borda was more similar to Fase 3, in advanced stage of succession, and Araucaria was the most different of all (Fig. 1).

Species Composition: A total of 106 Alticini species were collected during the two years of sampling (Table I; see also Table III in Linzmeier et al. 2006). The area of Borda had the highest richness whereas the lowest was recorded in the Araucaria area.

Of the 106 species, only seven $(6.6 \%)$ were collected in all areas, while $69(65 \%)$ were exclusives, that is, collected in only one of the five areas (Linzmeier et al. 2006). The Borda area had the highest number of exclusive species (30), representing more than half $(54.5 \%)$ of the species collected, while the Araucaria area had the lowest number, five exclusives species $(19.2 \%)$. The following numbers of exclusives species were recorded in successional areas: Fase 1, nine species (30\%), Fase 2, 15 species $(37.5 \%)$ and Fase 3, 10 species (34.5\%). The number of shared species between pairs of areas ranged from nine to 17 , representing $16 \%$ to $33.3 \%$ of the total collected between each pair of areas.

Regarding species composition, the areas of Araucaria and Fase 1, and Araucaria and Fase 2 were the most similar, with values of Jaccard coefficient of 0.33 and 0.32 , respectively (Fig. 2). The areas of Borda and Fase 3 were the most dissimilar, with only 12 shared species.

Temporal dynamics

Community Structure: Alticini community structure was more similar in the same area in different years than between different areas (Fig. 3). The Araucaria area had the community structure more similar between years.

Table I. Abundance (N) and richness (S) of Alticini trapped with malaise in five areas in the Parque Estadual de Vila Velha, Ponta Grossa, Parana, from September/1999 to August/2001.

\begin{tabular}{|c|c|c|c|}
\hline & Areas & $(\mathrm{N})$ & $(\mathrm{S})$ \\
\hline \multirow{5}{*}{$1999-2000$} & Borda & 94 & 39 \\
\hline & Araucaria & 140 & 16 \\
\hline & Fase 1 & 296 & 28 \\
\hline & Fase 2 & 342 & 30 \\
\hline & Fase 3 & 106 & 23 \\
\hline \multicolumn{2}{|c|}{ Subtotal } & 978 & 84 \\
\hline \multirow{5}{*}{$2000-2001$} & Borda & 100 & 36 \\
\hline & Araucaria & 144 & 19 \\
\hline & Fase 1 & 108 & 10 \\
\hline & Fase 2 & 418 & 28 \\
\hline & Fase 3 & 143 & 22 \\
\hline \multicolumn{2}{|c|}{ Subtotal } & 913 & 76 \\
\hline \multirow{5}{*}{$1999-2001$} & Borda & 194 & 55 \\
\hline & Araucaria & 284 & 26 \\
\hline & Fase 1 & 404 & 30 \\
\hline & Fase 2 & 760 & 40 \\
\hline & Fase 3 & 249 & 29 \\
\hline \multicolumn{2}{|c|}{ Total } & 1,891 & 106 \\
\hline
\end{tabular}


Species Composition: The same dynamic can be seen for species composition among the years. Except for the area Fase 1 , the other sampling areas were more similar to each other in the different years than among different areas (Fig. 4). Based on the values of Jaccard Coefficient, the area Fase 1 of the first year was more similar to Araucaria of the second year, while Fase 1 of the second year was more similar to Araucaria of the first year. Fase 1 had the largest change in the species composition from year to year among all sets of areas. In this area only $26.7 \%$ of the species were collected in both years, while $66.7 \%$ were collected in the first year and only $6.6 \%$ in the second. The area Fase 3, which is in a better state of conservation, presented the highest value of similarity $(0.81)$. In this area, more than half of the species were collected in both years, with $24.1 \%$ of the species being exclusives to the first year and $20.7 \%$ to the second. The other areas showed the following percentage of shared species between years: Fase 2 with $45 \%$, Borda with $36.4 \%$ and Araucaria with $34.6 \%$. Among all areas, only in Araucaria, more species were collected in the second year than in the first.

\section{DISCUSSION}

\section{Spatial dynamics}

Community Structure: Ganho \& Marinoni (2006) studying the Coleoptera in a gradient of natural forest and a reforestation of Pinnus ellioti Engelmann, verified lower abundance of Chrysomelidae in the natural forest edge. The same is shown for Alticini in this paper, where the lowest abundance was in Borda area, which is a grassland-forest edge. As approximately $60 \%$ of Chrysomelidae trapped by malaise belongs to Alticini (Linzmeier et al. 2006), we expect that most chrysomelids collected by Ganho \& Marinoni (2006) could also belong to Alticini, which are responding similarly to the forest edge. However, in the reforestation of Pinnus, the authors verified an increase in the abundance from interior towards the edge, which was associated with an increase of shrubs and herbs observed in this gradient. Probably in the reforestation of Araucaria, which is a native plant, other herbs and shurhs settle among them creating an environment favorable to Alticini, that result in a higher abundance pattern in Araucaria reforestation when compared to Pinnus.

The area that represents an ecotone, Borda, although with less similar species composition among all areas, showed the community structure more similar to area Fase 3 . The species that occur in these two areas, despite being very distinct, present similar abundance distribution, with low dominance. The areas Fase 1 and Fase 2, which showed more similar community structure, also have the most similar abundance distribution (see Table III in Linzmeier et al. 2006).

The high dissimilarity between the areas Fase 3 and Araucaria is due to the fact that this areas are opposite in dominance. While the area Fase 3 was the most uniform, the area of Araucaria had the highest dominance due to Trichaltica elegantula Baly, 1876 (Linzmeier et al. 2006), which had abundance values 6.5 times greater than the second most

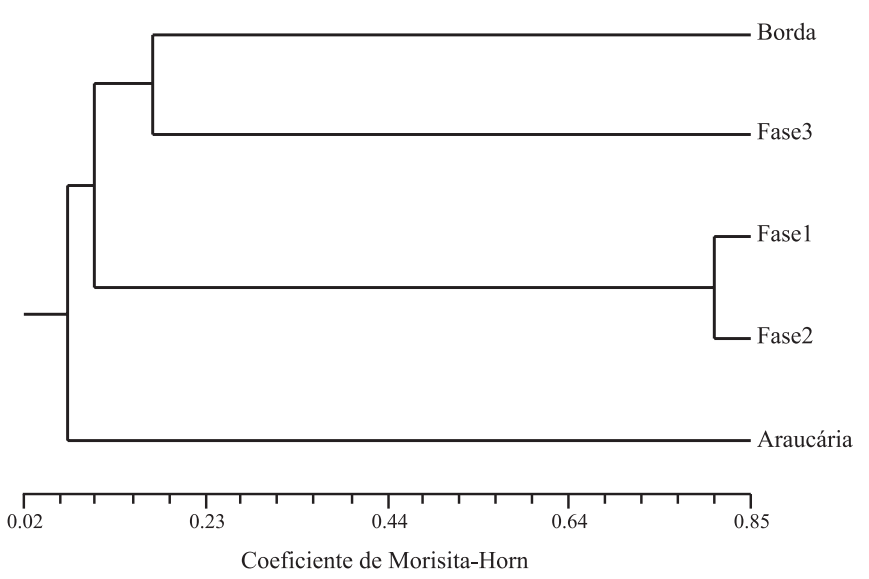

Fig. 1. Cluster Analysis. Morisita-Horn Coefficient $(c c=0.98)$. Data of Alticini abundance trapped with malaise in five areas in the Parque Estadual de Vila Velha, Ponta Grossa, Parana, from September/1999 to August $/ 2001$.

collected species in this area. For the other areas this difference was not greater than three times. Trichaltica elegantula was found abundantly in blooming plants of Allophylus edulis (A. St. Hil. \& al.) Radlk (Sapindaceae) (personal observation of the first author). This plant was recorded only in this area (Ganho \& Marinoni 2003). So, the overdominace of this species could be linked to the spatial organization of its host plant.

Species Composition: The percentage of exclusives and common species of Alticini were similar to those found in Coleoptera by Marinoni \& Ganho (2006) with 59\% and 4\%, respectively, and in Syrphidae (Diptera) (Jorge et al. 2007) with $51.5 \%$ and $4.2 \%$, respectively, both studies developed at the same sampling areas. This indicates that despite the close proximity among sampling areas (minimum and maximum distances of $70 \mathrm{~m}$ and $1,200 \mathrm{~m}$, respectively) and even the different taxa sampled (Diptera and Coleoptera), the number of shared species is very low, suggesting that the disctinct characteristics from each sampling areas are manintaining the high beta diversity.

For Alticini, as well as Coleoptera in general and Syrphidae, the ecotone sampling area, Borda, had the highest percentage of exclusive species. The lowest percentage for Alticini and Coleoptera were in the Araucaria area and to Syrphidae in the Fase 3 area. For Alticini, the higher richness and the higher number of exclusive species registered in the Borda area could be due to the high number of herbaceous species, which are their main food supply, a characteristic not found in the interior of the forest. According to Magura et al. (2001), more herbaceous plants in the edge provide an increase in the amount of herbivores. Besides it, several studies had reported the existence of species that are edge specialists, which are being benefited by the fragmentation (Cusson et al. 1990; Magura et al. 2001; Driscoll \& Weir 2005).

According to Jorge et al. (2007), Syrphidae in the Borda area have a greater availability of niche which allows a greater food supply both to the larvae (predators) as for the adults 


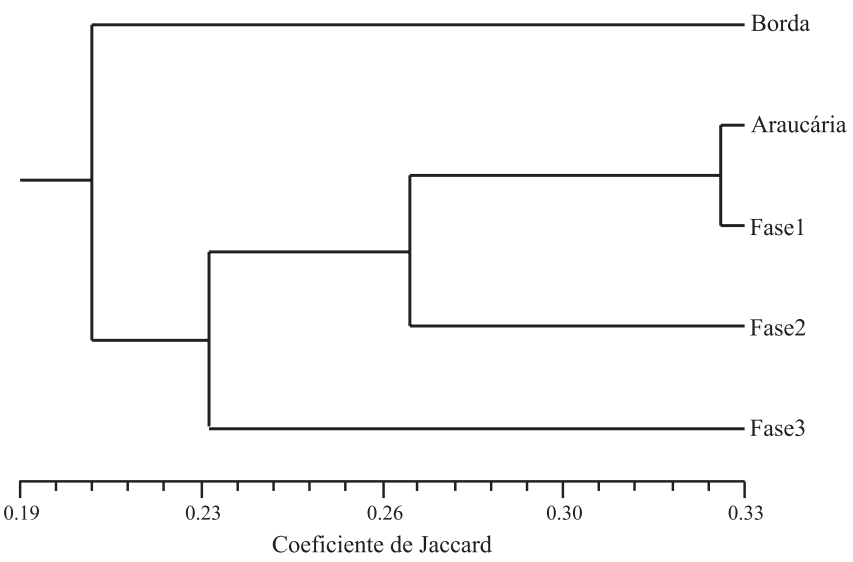

Fig. 2. Cluster Analysis. Jaccard Coefficient $(\mathrm{cc}=0.72)$. Data of presence/absence of Alticini trapped with malaise in five areas in the Parque Estadual de Vila Velha, Ponta Grossa, Parana, from September/ 1999 to August/2001.

(flower visitors). Thus, not only Syrphidae but also Alticini, Carabidae and Curculionidade (unpublished data) seem to be more related to open areas having higher anthropogenic interference or in early stages of succession. The Alticini species composition of the Borda and of the areas considered more conserved, Fase 2 and Fase 3, were the most dissimilar, as well as for whole Coleoptera (Marinoni \& Ganho 2006) and Syrphidae (Jorge et al. 2007). Didham et al. (1998) studying the effects of fragmentation on beetles species composition in fragments in Central Amazon, also observed that the greatest differences in the species composition occurred among edge areas and continuous forests.

Marinoni \& Ganho (2006) and Jorge et al. (2007) found that areas in more advanced stage of vegetal succession, Fase 2 and Fase 3, showed more similarity in species composition. Contrary to this findings, Alticini species composition in the areas Fase 1, Araucaria and Fase 2 were the most similar (Fig. 2). The Araucaria area, in spite of be a homogeneous plantation of Araucaria, after nearly 20 years without being managed, is populated with plants that occur in Fase 1 and Fase 2.

Taking into account that herbivores species are dominant in early succession stages (Morris 1980; Hutcheson 1990; Marinoni \& Dutra 1997; Linzmeier et al. 2006) and that for Alticini, as an herbivorous group, the Araucaria area was related both to the area in early successional stage as in intermediate successional stage, it can be inferred that the Araucaria area is in a successional stage intermediary to the areas Fase 1 and Fase 2.

In addition to the floristic characteristics, another factor that could be influencing the similarity relationship between the areas is the distance, since it is expected that among the closest areas the composition will be more similar than between the most distant areas (Cody 1986). However, the areas Fase 1 and Fase 2 which are the closest $(70 \mathrm{~m})$ were not the most similar, and the areas Fase 2 and Fase 3, the most conserved and which are more distant $(1,200 \mathrm{~m})$ had the third highest value of similarity, with 14 shared species, five of them occurring only in these areas.
Thus it confirms the importance of floristic characteristics in each area, which is in different levels of conservation, after anthropogenic interference, for the Alticini species composition.

Temporal dynamics

Community Structure: The community structure between the years had a greater similarity than among different areas. The relationship formed between the Borda $\left(\mathrm{B}_{1}\right.$ and $\left.\mathrm{B}_{2}\right)$ and Fase $3\left(\mathrm{~F} 3_{1}\right.$ and $\left.\mathrm{F} 3_{2}\right)$ and, Fase $1\left(\mathrm{~F} 1_{1}\right.$ and $\left.\mathrm{F} 1_{2}\right)$ and Fase $2\left(\mathrm{~F} 2_{1}\right.$ and $\mathrm{F}_{2}$ ) remained. The spatial analysis in the Araucaria showed that it is the most differentiated of all areas. In the temporal analysis it was more similar to the Borda and Fase 3 areas. The high abundance of $T$. elegantula, that in the spatial analysis made the Araucaria area to be the most differentiated of all sampling units, since the Morisita-Horn coefficient is affected by the most abundant species, here it was divided into first and second years, reducing the discrepancy of data. Thus, the community structure of the Araucaria area between the years was more similar to Borda and Fase 3 areas.

Species Composition: The communities are temporally dynamic since they gain and lose species over time (Fridley et al. 2006). For Alticini, in general there was a greater similarity in the species composition between the years than among the areas. Only in Fase 1 this result has not been confirmed. In this area, in the second year of collection a huge decrease in the number of species was observed, that is, of the 30 recorded species, eight were collected in both years, 20 were exclusive of the first year and only two were collected in the second year. Thus, similarly to Brown (1984), early successional stages are characterized by a rapid change in the species composition. It appears that there was a huge loss of species from the first

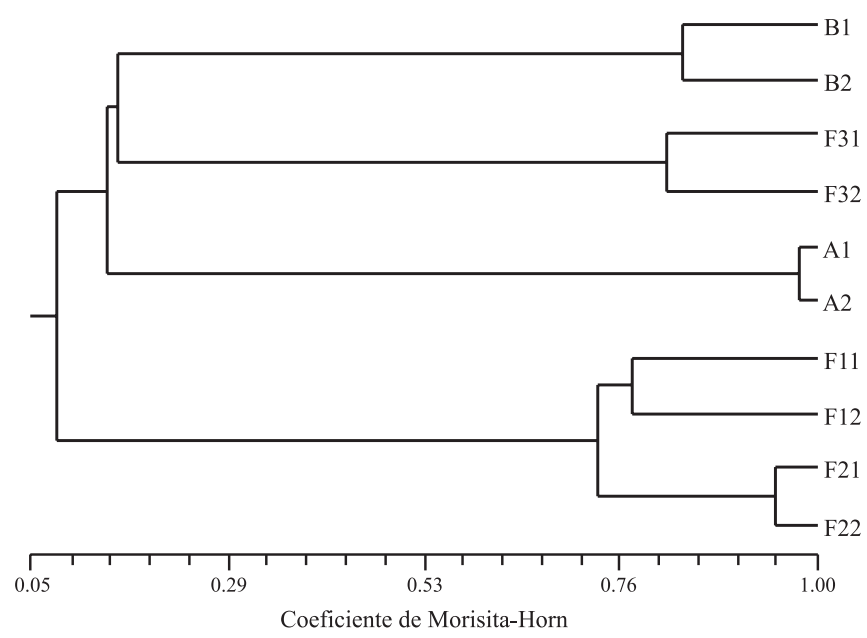

Fig. 3. Cluster Analysis. Morisita-Horn Coefficient ( $\mathrm{cc}=0,98)$. Data of Alticini abundance trapped with malaise in five areas in the Parque Estadual de Vila Velha, Ponta Grossa, Parana, from September/1999 to August $/ 2001$. ( $\mathrm{B}_{1}$ : Borda of $1^{\text {st }}$ year; $\mathrm{B}_{2}$ : Borda of $2^{\text {nd }}$ year; $\mathrm{A}_{1}$ : Araucaria of $1^{\text {st }}$ year; $A_{2}$ : Araucaria of $2^{\text {nd }}$ year; F1 $1_{1}$ : Fase 1 of $1^{\text {st }}$ year; F $1_{2}$ : Fase 1 of $2^{\text {nd }}$ year; F2 1 : Fase 2 of $1^{\text {st }}$ year; F2: Fase 2 of $2^{\text {nd }}$ year; F $3_{1}$ : Fase 3 of $1^{\text {st }}$ year; $F 3_{2}$ : Fase 3 of $2^{\text {nd }}$ year). 


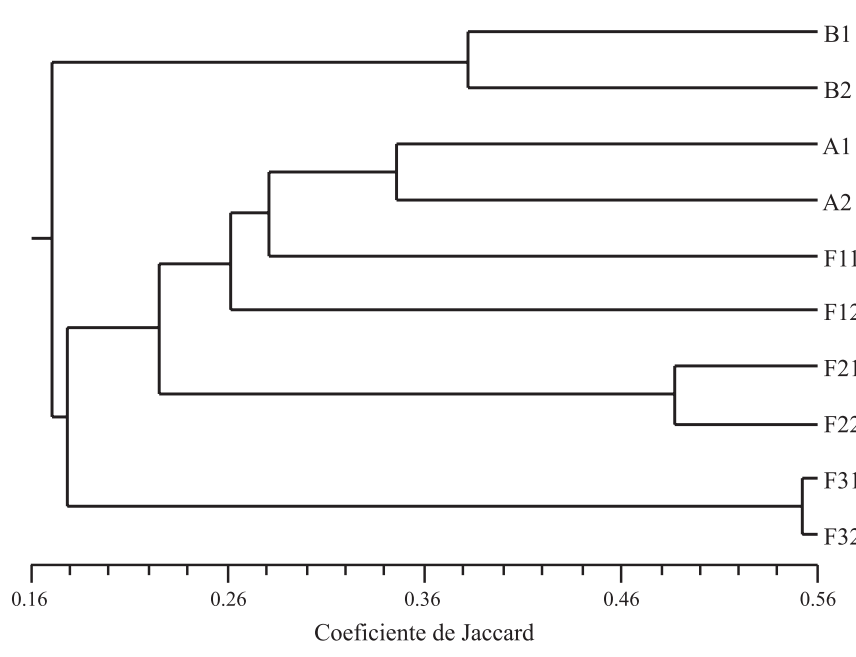

Fig. 4. Cluster Analysis. Jaccard Coefficient $(\mathrm{cc}=0.91)$. Data of presence/absence of Alticini trapped with malaise in five areas in the Parque Estadual de Vila Velha, Ponta Grossa, Parana, from September/ 1999 to August/2001. ( $B_{1}$ : Borda of $1^{\text {st }}$ year; $B_{2}$ : Borda of $2^{\text {nd }}$ year; $A_{1}$ : Araucaria of $1^{\text {st }}$ year; $\mathrm{A}_{2}$ : Araucaria of $2^{\text {nd }}$ year; $\mathrm{F} 1_{1}$ : Fase 1 of $1^{\text {st }}$ year; $\mathrm{F} 1_{2}$ : Fase 1 of $2^{\text {nd }}$ year; $F 2_{1}$ : Fase 2 of $1^{\text {st }}$ year; F2 2 : Fase 2 of $2^{\text {nd }}$ year; F 3 : Fase 3 of $1^{\text {st }}$ year; F3 : Fase 3 of $2^{\text {nd }}$ year).

to the second year, though the cause of this variation is not known.

The Fase 3 area, with a best conservation state, had the highest value of similarity, being the most stable area between the two years. Wolda (1996) also recorded changes in the fauna between years, indicating that the similarity between years in a location is bigger than between locations.

It would also appear that the relationships of the groups of the different areas are maintained and, that Araucaria remains between the areas Fase 1 and Fase 2 as seen earlier in spatial analysis.

\section{CONCLUSION}

The high percentage of exclusive species in the Borda area was similar to those found for different groups of Coleoptera in general, and Curculionidae and Syrphidae separately. It is probable that this pattern will be repeated in other groups due their necessities, and the special characteristics found in the Borda. But studies of groups that have different habits are needed to confirm this pattern.

Based on the Alticini species composition, the Araucaria area is in an intermediate successional stage, between the succession areas Fase 1 and Fase 2, confirming thus, the importance of the floristic features in the species composition of this group.

As for the community structure over time, the Araucaria area was the most similar between years because of the dominance of T. elegantula.

The species composition in the areas changed significantly between years. However, as the conservation status raised, within the succesional process, a more stable community was found leading to a greater similarity and a higher number of shared species of Alticini between years.

The area with greater human interference, Borda, had an increase in the Alticini richness as verified in other insect groups.

Generally, for Alticini, small environmental changes caused both naturally and by humans, which could provide more environmental heterogeneity, should increase the diversity of the group in the Araucaria Forest of the Southern of Brazil.

Acknowledgments. We would like to thank to Dr. Renato Contin Marinoni (Universidade Federal do Paraná) for the discussions and material provided. To Dr. Alexander S. Konstantinov (National Museum of Natural History - Smithsonian Institution) for his suggestions on the manuscript. To Fernando Mayer (Museu Anchieta de Porto Alegre) and Dr. Luciano de A. Moura (Museu de Ciências Naturais, Fundação Zoobotânica do Rio Grande do Sul) for the access to the collections and to the Conselho Nacional de Desenvolvimento Científico e Tecnológico, for the Doctoral Fellowship to the first author and the Fellowship to the second author.

\section{REFERENCES}

Basset, Y. \& G. A. Samuelson. 1996. Ecological characteristics of an arboreal community of Chrysomelidae in Papua New Guinea, p. 243-262. In: P. H. A. Jolivet \& M. L. Cox (eds). Chrysomelidae Biology: Ecological Studies. Amsterdam, Academic Publishing, $465 \mathrm{p}$.

Britez, R. M.; P. L. Castella \& L.A. Pires. 2000. Estratégia de conservação da floresta com araucária para o estado do Paraná, p. 731-737. In: M. S. Milano \& V. Theulen (Eds). Anais do Congresso Brasileiro de Unidades de Conservação. Campo Grande, xvi +845 p.

Brown, V. K. 1984. Secondary Succession: insect-plant relationships. BioScience 34: 710-716.

Castella, P. R.; R. M. Britez \& S. B. Mikich. 2004. Áreas prioritárias de floresta com araucária para conservação no Estado do Paraná, p. 134-143. In: Milano, M. S.; L. Y. Takahashi \& M. L. Nunes (coord.). IV Congresso Brasileiro de Unidades de Conservação. Anais. Vol 1. Curitiba. Fundação O Boticário de Proteção à Natureza. Rede Nacional Pró Unidades de Conservação, $718 \mathrm{p}$.

Cody, M. L. 1986. Diversity, rarity, and conservation in Mediterraneanclimate regions, p. 122-152. In: M. E. Soulé (ed.). Conservation Biology. Sunderland, Sinauer Associates, xiii +584 p.

Cusson, M.; R. S. Vernon \& B. D. Roitgerg. 1990. A sequential sampling plan for adult tuber flea beetles (Epitrix tuberis Gentner): dealing with "edge effects." The Canadian Entomologist 122: $537-$ 546.

Didham, R. K.; P. M. Hammond; J. H. Lawton; P. Eggleton \& N. E. Stork. 1998. Beetle species responses to tropical forest fragmentation. Ecological Monographs 68: 295-323.

Driscoll, D. A. \& T. Weir. 2005. Beetle responses to habitat fragmentation depend on ecological traits, habitat condition, and remnant size. Conservation Biology 19: 182-194.

Farrell, B. D. \& T. L. Erwin. 1988. Leaf-beetle community structure in an amazonian rainforest canopy, p. 73-90. In: Jolivet, P.; E. Petitpierre \& T. Hsiao (eds). Biology of Chrysomelidae. Kluwer Academic Publ., Dordrecht, 608 p.

Frenzel, M. \& R. Brandl. 2001. Hosts as habitats: faunal similarity of phytophagous insects between host plants. Ecological Entomology 26: 594-601.

Fridley, J. D.; R. K. Peet; E. Maarel \& J. H. Willems. 2006. Integration of local and regional species-area relationships from space-time species accumulation. The American Naturalist 168: 133-143. 
Fundação de Pesquisas Florestais do Paraná (Fupef). 2001. Conservação do Bioma Floresta com Araucária: relatório final Diagnóstico dos remanescentes florestais. 2v. FUPEF. Curitiba, $124 \mathrm{p}$.

Furth, D. G. 1988. The jumping apparatus of flea beetles (Alticinae), p. 285-297. In: Jolivet, P.; E. Petitpierre \& T. Hsiao (eds). Biology of Chrysomelidae. Kluwer Academic Publishers, Dordrecht, 608 p.

Ganho, N. G. \& R. C. Marinoni. 2003. Fauna de Coleoptera no Parque Estadual de Vila Velha, Ponta Grossa, Paraná, Brasil. Abundância e riqueza das famílias capturadas através de armadilhas malaise. Revista Brasileira de Zoologia 20: 727-736.

Ganho, N. G \& R. C. Marinoni. 2006. A variabilidade espacial das famílias de Coleoptera (Insecta) entre fragmentos de Floresta Ombrófila Mista Montana (Bioma Araucária) e plantação de Pinus elliottii Engelmann, no Parque Ecológico Vivat Floresta, Tijucas do Sul, Paraná, Brasil. Revista Brasileira de Zoologia 23: 11591167.

Gering, J. C. \& T. O. Crist. 2002. The alpha-beta-regional relationship: providing new insights into local-regional patterns of species richness and scale dependence of diversity components. Ecology Letters 5: 433-444.

Hutcheson, J. 1990. Characterization of terrestrial insect communities using quantified, Malaise-trapped Coleoptera. Ecological Entomology 15: 143-151.

Jolivet, P. 1988. Food habits and food selection of Chrysomelidae: Bionomic and evolutionary perspectives, p. 1-24. In: Jolivet, P. \& T. H. Hsiao (eds). Biology of Chrysomelidae. Kluwer Academic Publishers, Dordrecht, 608 p.

Jolivet, P. \& E. Petitpierre. 1976. Selection trophique et évolution chromosomique chez les Chrysomelinae (Coleoptera: Chrysomelidae). Acta Zoologica et Pathologica Antverpiensia 66: 59-90.

Jolivet, P. \& T. Hawkeswood. 1995. Host-Plants of Chrysomelidae of the World. An Essay about relationships between the Leaf-beetles and their Food-plants. Backhuys Publishers. Leiden. $281 \mathrm{p}$.

Jorge, C. M.; L. Marinoni \& R. C. Marinoni. 2007.Diversidade de Syrphidae (Díptera) em cinco áreas com situações florísticas distintas no Parque Estadual de Vila Velha em Ponta Grossa, Paraná. Iheringia, Série Zoológica 97: 452-460.

Leps, J.; V. Novotný \& Y. Basset. 2001. Habitat and successional status of plants in relation to the communities of their leaf-chewing herbivores in Papua New Guinea. Journal of Ecology 89: 186199.

Linzmeier, A. M.; C. S. Ribeiro-Costa \& R. C. Marinoni. 2006. Fauna de Alticini (Newman, 1834) (Coleoptera, Chrysomelidae, Galerucinae) em áreas com diferentes tipos de manejo e níveis de preservação vegetal na Floresta de Araucária do Paraná, Brasil: diversidade e estimativa de riqueza de espécies. Revista Brasileira de Entomologia 50: 101-109.

Maack, R. 1981. Geografia Física do Estado do Paraná. José Olympio Editora, Rio de Janeiro, $450 \mathrm{p}$.

Magura, T.; B. Tóthmérész \& T. Molnár. 2001. Forest edge and diversity: carabids along forest-grassland transects. Biodiversity and Conservation 10: $287-300$.

Magurran, A. E. 1988. Ecological diversity and its measurement. Princeton, New Jersey, Princeton University Press, 179 p.

Magurran, A. E. 2004. Measuring biological Diversity. Blackwell Publishing, $256 \mathrm{p}$.

Marinoni, R. C. \& R. R. C. Dutra. 1997. Famílias de Coleoptera capturadas com armadilha Malaise em oito localidades do Estado do Paraná, Brasil. Diversidades alfa e beta. Revista Brasileira de Zoologia 14: 751-770.

Marinoni, R. C. \& N. G. Ganho. 2006. A diversidade diferencial beta de Coleoptera (Insecta) em uma paisagem antropizada do Bioma Araucária. Revista Brasileira de Entomologia 50: 64-71.

Morris, M. G. 1980. Insects and the Environment in the United Kingdom. Atti XII Congresso Nazionale Italiano di Entomologia, Roma. 203-235 p.

Novotný, V.; Y. Basset; G. A. Samuelson \& S. E. Miller. 1999. Host use by chrysomelid beetles feeding on Moraceae and Euphorbiaceae in New Guinea, p. 545-555. In: Cox, M. L. Advances in Chrysomelidae Biology 1. Backhuys Publishers, Leiden, The Netherlands, $671 \mathrm{p}$.

Novotný, V. \& G. D. Weiblen. 2005. From communities to continents: beta diversity of herbivorous insects. Annales Zoologici Fennici 42: 463-475.

Rohlf, F. J. 1989. NTSYS-PC. Numerical Taxonomy and Multivariate Analysis System. New York, Exeter Publ. Ltd, $187 \mathrm{p}$.

Scherer, G. 1988. The origins of the Alticinae, p. 115-130. In: Jolivet, P.; E. Petitpierre \& T. Hsiao (eds). Biology of Chrysomelidae. Kluwer Academic Publ., Dordrecht, 608 p.

Takizawa, H. 1994. Seasonal changes in leaf beetle fauna of a warm temperate lowland in Japan, p. 511-525. In: Jolivet, P. H.; M. L. Cox \& E. Petitpierre (eds). Novel aspects of the biology of Chrysomelidae. Kluwer Academic Publishers, Netherlands, 582p.

Townes, H. 1972. A light-weight malaise trap. Entomological News 83: 239-247.

Wagner, T. 1999. Arboreal chrysomelid community structure and faunal overlap between different types of forests in Central África, p. 247-270. In: Cox, M. L. (ed.). Advances in Chrysomelidae Biology 1. Backhuys Publishers, Leiden, The Netherlands, $671 \mathrm{p}$.

Wolda, H. 1996. Between-site similarity in species composition of a number of Panamanian insect groups. Miscellánia Zoológica 19: $39-50$. 